\title{
Survival strategies of stingless bees (Melipona subnitida) in an unpredictable environment, the Brazilian tropical dry forest
}

\author{
Camila MaIA-SILvA ${ }^{1,2}$, Michael $\operatorname{HrNCIR}^{2}$, Claudia Inês da SILVA ${ }^{1,3}$, \\ Vera Lucia IMPERATRIZ-FONSECA ${ }^{1,2}$ \\ ${ }^{1}$ Faculdade de Filosofia, Ciências e Letras de Ribeirão Preto, Universidade de São Paulo, Avenida Bandeirantes 3900, \\ Ribeirão Preto, SP 14040-901, Brasil \\ ${ }^{2}$ Departamento de Ciências Animais, Universidade Federal Rural do Semi-Árido, Avenida Francisco Mota 572, \\ Mossoró, RN 59625-900, Brasil \\ ${ }^{3}$ Departamento de Zootecnia, Universidade Federal do Ceará, Avenida Mister Hull 2977, Campus do Pici, Bloco 808, \\ Fortaleza, CE 60021-970, Brasil
}

Received 23 July 2014 - Revised 15 January 2015 - Accepted 30 January 2015

\begin{abstract}
Unpredictable environments are a challenge to highly eusocial bees because unreliable food availability, owing mainly to seasonally unpredictable precipitation rates, renders the maintenance of permanent colonies difficult. Here, we investigated the strategy of the stingless bee Melipona subnitida to cope with elevated temperatures and extended, irregular periods of drought in the Brazilian tropical dry forest. We found a high association between colony behaviour (pollen foraging and brood production) and environmental parameters (abiotic factors and availability of pollen sources), suggesting that colonies tightly adjust their activities to the respective environmental conditions. This minimises unnecessary costs related to foraging and brood rearing when forage availability is low. Additionally, M. subnitida selectively foraged at the most lucrative pollen-sources (massflowering trees, plants with poricidal flowers), which indicates that the colonies maximise their food intake as soon as resources are available.
\end{abstract}

\section{Caatinga / floral resources / pollen foraging / brood-cell construction}

\section{INTRODUCTION}

One of the premises for classifying a social insect as highly eusocial is that its colonies are long-lived (Wilson 1971; Michener 1974). Among the bees, there are two groups of highly eusocial species, the stingless bees (Apidae, Meliponini, over 500 species; Michener 2013) and the honey bees (Apidae, Apini, about 11

Electronic supplementary material The online version of this article (doi:10.1007/s13592-015-0354-1) contains supplementary material, which is available to authorized users.

Corresponding author: C. Maia-Silva, maiasilvac@gmail.com

Manuscript Editor: James Nieh species; Michener 2007). Of these, temperate and subtropical species as well as species of many tropical regions live in largely predictable foraging environments, a fact that facilitates the maintenance of perennial colonies. On the one hand, bees of temperate, subtropical, and seasonal tropical environments experience a predictable foraging season, followed by a likewise predictable season without floral resources. When periods of food scarcity are imminent, colonies of highly eusocial bees increase their foraging activity and amass food stores within the nest (Lindauer 1948; Michener 1974; KleinertGiovannini 1982; Roubik 1982; Seeley 1985; Rinderer 1988). Bees living in the non-seasonal tropics, on the other hand, do not experience severe variations in food availability throughout the year 
and, consequently, have virtually year-round access to resources in the environment (Bawa 1983; Wilms and Wiechers 1997; Kajobe and Echazarreta 2005). Here, in contrast to seasonally changing environments, the accumulation of food reserves has little relevance for sustaining longlived colonies (Schneider and Blyther 1988; McNally and Schneider 1992).

In strong contrast to these predictable foraging environments, unpredictable environments pose a challenge to highly eusocial bees. Temporally unreliable food availability, often due to unpredictable climatic conditions throughout the year, renders the maintenance of permanent colonies in these environments difficult. Here, the strategy of honey bees is to abandon a location in which environmental conditions are unfavourable and to migrate into areas of greater resource abundance (seasonal absconding) (Michener 1974; Schneider and McNally 1992a, b; Freitas et al. 2007). In stingless bees, however, absconding is rare (although not impossible). This is largely due to the fact that mated meliponine queens are unable to fly, and the colonies would have to leave their queen behind when moving to a new nesting site (Michener 1974). Consequently, stingless bees are much more constrained to a given nest location than are honey bees, and putatively developed alternative strategies to sustain permanent colonies in unpredictable environments.

An unpredictable environment, and particularly challenging for highly eusocial bees, is the Brazilian tropical dry forest, the Caatinga. The climate of this ecoregion in northeastern Brazil is classified as semi-arid with elevated annual temperatures and extended periods of drought (Prado 2003). Here, blooming of the vast majority of flowering plants occurs during a very short, yet unpredictable rainy season (Zanella and Martins 2003; Machado and Lopes 2004; Maia-Silva et al. 2012). Probably due to these extreme environmental conditions and the associated shortage of floral resources over long, irregular periods of the year, only few meliponine species naturally occur in this biome (Zanella 2000; Zanella and Martins 2003).

The purpose of the present study was to investigate the survival strategies of the stingless bee Melipona subnitida in the Brazilian tropical dry forest. Specifically, we were interested in how this bee species sustains perennial colonies in this unpredictable environment. Since $M$. subnitida is not known for seasonal absconding, colonies should show alternative behavioural responses to unfavourable environmental conditions. We evaluated (1) the influence of environmental factors on external (pollen foraging) and internal activities (brood-cell construction) and (2) the pollen resources collected by the colonies.

\section{MATERIAL AND METHODS}

\subsection{Study site and bee species}

The study was performed from May, 2011 through May, 2012 in a $210,000-\mathrm{m}^{2}$ area of native Caatinga vegetation at the Experimental Field Station Rafael Fernandes of the Brazilian National University of Agriculture (UFERSA) in Mossoró-Rio Grande do Norte $\left(5^{\circ} 03^{\prime} 54.45^{\prime \prime} \mathrm{S}, 37^{\circ} 24^{\prime} 03.64^{\prime \prime} \mathrm{W}\right.$; altitude, $\left.79 \mathrm{~m}\right)$. The region is characterised by a hot and semi-arid climate with an average annual rainfall of between 500 and $800 \mathrm{~mm}$ and deciduous thorn vegetation (Velloso et al. 2002). We investigated four colonies of the stingless bee species M. subnitida Ducke 1910 (Apidae, Meliponin), housed in wooden nest-boxes that had been installed within the study area 3 months prior to the onset of the observations. The geographic distribution of M. subnitida, popularly known as "jandaira", is restricted to the states of northeastern Brazil (Zanella 2000; Camargo and Pedro 2012). It naturally nests in narrow cavities (diameter $\approx 10 \mathrm{~cm}$; length $\approx 115 \mathrm{~cm}$ ) preferentially of the native tree species Commiphora leptophloeos (Burseraceae), Poincianella bracteosa (Fabaceae, Caesalpinioidae), and Myracrodruon urudeuva (Anacardiaceae) (Cámara et al. 2004; Martins et al. 2004). Worker populations vary from $<100$ individuals during the dry period to $>1500$ during the rainy season (CMS, MH, personal observation).

\subsection{Environmental factors}

For each month of our study, we calculated the following environmental variables (EV): $\mathrm{T}_{\mathrm{AVG}}$, average temperature $\left({ }^{\circ} \mathrm{C}\right) ; \mathrm{T}_{\mathrm{MAX}}$, maximum temperature $\left({ }^{\circ} \mathrm{C}\right)$; $\mathrm{T}_{\mathrm{MIN}}$, minimum temperature $\left({ }^{\circ} \mathrm{C}\right)$; $\mathrm{RH}_{\mathrm{AVG}}$, average relative humidity (\%); RAIN, total precipitation ( $\mathrm{mm}$ ); SUN, average time of sunrise; and P-FLO, total number 
of plant species available as potential pollen sources. Data on abiotic variables were obtained from a weather station of the National Institute of Meteorology (INMET, weather-station number A318), at a distance of approximately $4 \mathrm{~km}$ from our study area. Since data on light intensity were not available, we used the time of sunrise as surrogate (obtained from the website: www.suncalc.net). From the monthly available potential pollen sources in the study area, we collected plant and pollen samples for species identification. Plant samples were deposited at the university's herbarium Dárdano de Andrade Lima (MOSS) and pollen samples at the university's pollen reference collection.

\subsection{Colony activity}

For each colony, we calculated the following monthly colony variables $(\mathrm{CV})$ : $\mathrm{F}_{\mathrm{ON}}$, average time of foraging onset; $F_{\text {PEAK, }}$ average time of peak activity; $F_{\text {END }}$, average end of pollen foraging activity; $\mathrm{F}_{\mathrm{MAX}}$, average maximum number of forages; P-COL, total number of plant species collected; and CONST, average brood-cell construction rate (brood cells per day). Unfortunately, due to the location particularly of the pollen storage pots underneath the brood combs, we could not reliably assess the amount of food reserves stored inside the colonies in the course of our study.

\subsubsection{Pollen foraging (colony variables $F_{O N}$, $F_{P E A K}, F_{E N D}$ and $\left.F_{M A X}\right)$}

Foraging activity of the colonies was assessed by counting the number of foragers returning to the nests with pollen loads between 0500 and 1200 hours. During peak activity (usually between 0500 and 0900 hours), the number of pollen foragers per colony was registered for $5 \mathrm{~min}$ at every $15 \mathrm{~min}$. When collecting activity decreased, bee counts were made for $5 \mathrm{~min}$ at every $30 \mathrm{~min}$. In the more humid months with elevated pollen collection, we recorded the colonies' foraging activity on 6 days/month. In the dry months, due to the general reduction in foraging activity of all colonies, we reduced the number of observations to 3 days/month. As foraging onset, we considered the first 5-min interval in which incoming pollen foragers were registered. The time of peak foraging activity was calculated as the acrofase (mean time vector) of the daily foraging activity counts of a colony (circular statistics software Oriana 4.0). As end of foraging activity, we considered the last 5-min interval in which pollen foragers returned to the colony, followed by at least two 5-min intervals with zero counts. For the statistical analyses, time data (hour: minute) were transformed into decimal numbers (hour+minutes $/ 60$, so that, e.g., 0550 hours became 5.83).

\subsubsection{Floral origin of pollen collected by bees (colony variable P-COL)}

Pollen sampling was performed twice or, when bee activity was high, three times between 0600 and 0900 hours on days on which we did not investigate the foraging activity (six sampling days in humid months, tree sampling days in dry months). For the sampling, nest entrances were blocked for a maximum of $5 \mathrm{~min}$, and the returning pollen foragers were captured individually in plastics vials. In order to avoid a significant reduction of the pollen foraging force on subsequent days, we caught a maximum of three bees during each collecting event (maximum of nine bees per colony per day). The bees were chilled on ice for $5 \mathrm{~min}$. Subsequently, the pollen pellets were removed from the individuals' corbiculae with alcohol-cleaned tweezers and stored in test tubes. After pollen removal, the foragers were released. The individual pollen samples were acetolysed following the methods described by Erdtman (1960), and the floral origin of the pollen loads was identified through comparison with reference material from university's pollen collection. To evaluate the relative composition of potentially mixed pollen loads, we identified the floral origin of 400 pollen grains of the pellets of each forager (Nagamitsu et al. 1999). Samples containing $\geq 95 \%$ of pollen grains of the same floral source were considered pure samples (Eltz et al. 2001). In samples containing two or more pollen types, we considered the most abundant type of pollen as the respective forager's principal pollen source (Nagamitsu et al. 1999).

\subsubsection{Brood-cell construction (colony variable CONST)}

Each month, we took digital pictures of the brood area of the colonies on three consecutive days at 24-h intervals. Through the comparison of two consecutive photos, we were able to assess the number of new brood cells constructed within the 24-h interval between recordings. 


\subsection{Data analysis}

The environmental parameter $T_{A V G}$ had descriptive purpose only and was excluded from the statistical analyses for being a linear combination of $\mathrm{T}_{\mathrm{MIN}}$ and $\mathrm{T}_{\mathrm{MAX}}$. The potential relationship between the monthly number of available pollen sources (P-FLO) and abiotic environmental factors ( $\mathrm{T}_{\mathrm{MAX}}, \mathrm{T}_{\mathrm{MIN}}, \mathrm{RH}_{\mathrm{AVG}}, \mathrm{RAIN}$ and $\mathrm{SUN}$ ) was assessed using multiple linear regression analysis (best subset regression model; Zar 1999). The adjusted coefficient of determination $R_{\mathrm{ADJ}}^{2}$ ( $R^{2}$ adjusted for the number of independent variables in the model) indicated the proportion of variability in the data explained by the model (for details, see Electronic Supplemental Material). Differences in colony activity along our study were analysed using two-way ANOVA (Tukey's test for pair-wise comparison), considering the month of observation (factor 1) and colony identity (factor 2) as possible sources of variation. Whenever necessary, data were square root transformed to improve normality (Zar 1999). To evaluate the potential interaction between environmental factors and colony activity, we used canonical correlation analysis, which quantifies the relationships between two sets of variables (Hotelling 1936), in our case, between environmental variables (EV, set 1$)$ and colony variables (CV, set 2) (for details, see Electronic Supplemental Material). Statistical analyses were performed using the software packages SigmaPlot 10.0/ SigmaStat 3.5 (Systat Software Inc., USA) and Statistica 8.0 (StatSoft Inc., USA). The $\alpha$-level for significant differences was $P \leq 0.05$.

\section{RESULTS}

\subsection{Environmental conditions}

The first 3 months of our study (May 2011July 2011) were more humid (average relative humidity, $\mathrm{RH}_{\mathrm{AVG}}>80 \%$; average monthly precipitation, $65.3 \pm 82.2 \mathrm{~mm}, 51 \%$ of total precipitation) and cooler (maximum temperatures, $\mathrm{T}_{\mathrm{MAX}}<32^{\circ} \mathrm{C}$ ) than the following months (August 2011-May 2012). Of these, the hottest and driest months were September 2011 through February $2012\left(\mathrm{RH}_{\mathrm{AVG}}<70 \%\right.$; average monthly precipitation, $13.0 \pm 20.6 \mathrm{~mm}, 16 \%$ of total precipitation; $\mathrm{T}_{\text {MAX }}>38{ }^{\circ} \mathrm{C}$ ). Environmental conditions in May 2011 (first month of study) were strikingly different from those in May 2012 (last month of study).
Whereas May 2011 was the wettest and coolest month of our study (precipitation, RAIN $=163 \mathrm{~mm}$, $41 \%$ of total precipitation; $\mathrm{RH}_{\mathrm{AVG}}=96.2 \%$; $\mathrm{T}_{\text {MAX }}=31.1{ }^{\circ} \mathrm{C}$ ), May 2012 was very dry (RAIN $=3 \mathrm{~mm}, 0.75 \%$ of total precipitation; $\left.\mathrm{RH}_{\mathrm{AVG}}=67.5 \%\right)$ and hot $\left(\mathrm{T}_{\mathrm{MAX}}=36.6{ }^{\circ} \mathrm{C}\right)$ (Figure 1a, b; Electronic Supplemental Material).

The variation concerning the plant species available as potential pollen sources during our study (PFLO: maximum, 37 species, May 2011; minimum, 3 species, January 2012; Figure 1c, Electronic Supplemental Material) was attributed to the variations in $\mathrm{RH}_{\mathrm{AVG}}$ and RAIN (best subset regression model: $\mathrm{P}-\mathrm{FLO}=-29.22+0.54 \times \mathrm{RH}_{\mathrm{AVG}}+0.07 \times \mathrm{RAIN}$; $\left.R_{\mathrm{ADJ}}^{2}=0.82 ; P<0.001\right)$. In accordance with the climatic differences observed between the first and last month of our study, the number of pollen sources was higher in May 2011 than in May 2012 (P$\mathrm{FLO}_{\text {May } 2011}=37$; P-FLO ${ }_{\text {May } 2012}=6$ ). In humid months with high precipitation, the majority of plant species in bloom were herbaceous species, whereas the few pollen sources available during the dry months were predominantly trees (Electronic Supplemental Material).

\subsection{Colony activity}

External (pollen foraging) and internal colony activity (brood-cell construction) varied significantly in the course of our study (Figure 2; Table I). For all studied parameters (foraging onset, peak activity, end of pollen foraging, maximum number of forages, number of plant species collected, brood-cell construction rate), this variation was attributed only to the month of study. Colony identity did not contribute significantly to the observed variation (Table I). In general, foraging was reduced (or absent) in the hot/ dry months of our study (September 2011 to January 2012) with the exception of November 2011, when we observed an elevated pollen collecting activity (Figure 2a, b). In the first 2 months of our study, brood production by the colonies was approximately 30 brood cells/ day. In the remaining months, this colonyinternal activity decreased by almost two thirds and dropped to a rate of below 12 brood cells/ day (below 9 brood-cells/day from September 2011 through December 2011), with the 

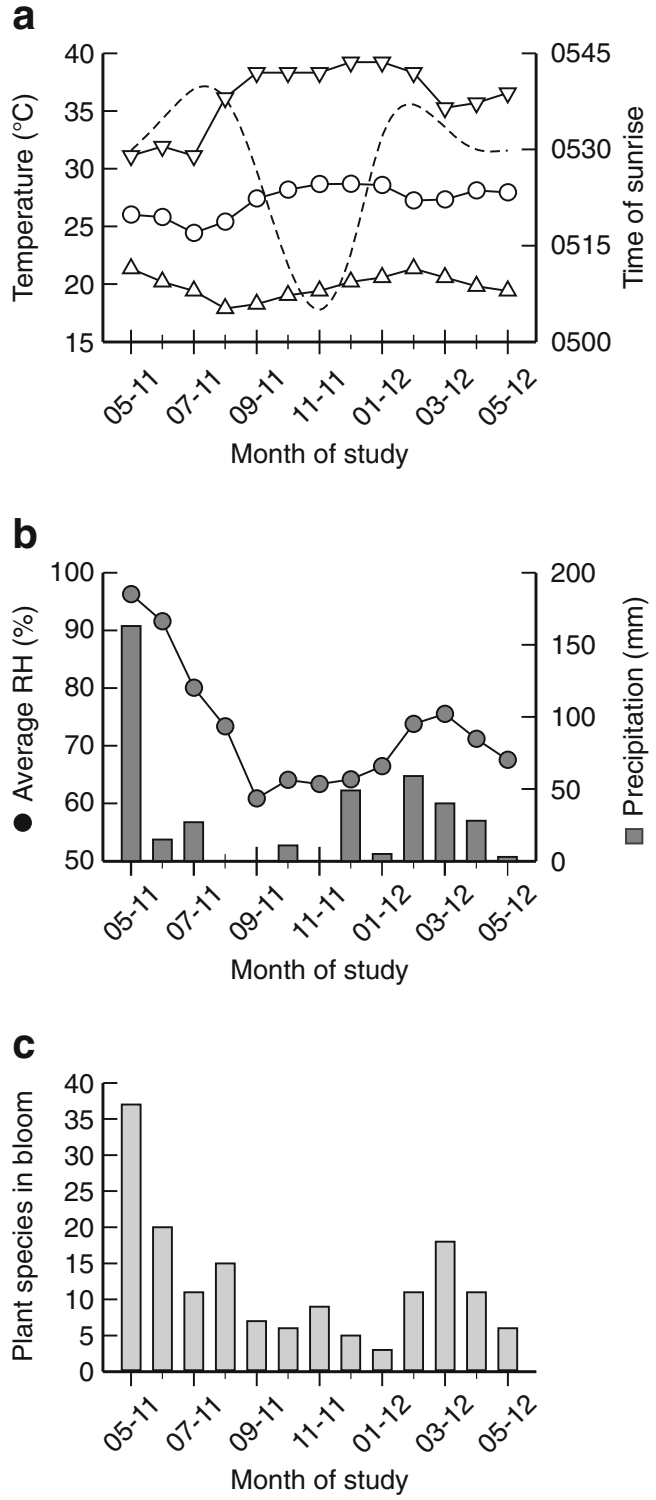

Figure 1. Variation of environmental parameters in the course of the study period (May 2011 to May 2012). a Monthly temperatures (down-pointing triangle maximum temperature, circle average temperature, upright triangle minimum temperature) and average time of sunrise (dashed line). b Monthly average relative humidity $(R H)$ (grey-filled circles ) and total precipitation (grey-filled bars ). c Number of flowering plant species in bloom in each month of the study.

exception of January and February 2012, when colonies temporarily increased their brood production to approximately 17 brood cells/ day (Figure 2d; Table I).

\subsection{Relationship between environmental conditions and colony activity}

We found a highly significant relationship between environmental conditions and colony activity. Canonical correlation analysis indicated three significant canonical functions that explained between almost $100 \%$ (function $\mathrm{I}, R_{\mathrm{C}}{ }^{2}=99.8 \%$; function II, $R_{\mathrm{C}}{ }^{2}=93.5 \%$ ) and $70 \%$ (function III, $R_{\mathrm{C}}{ }^{2}=70.4 \%$ ) of the variation found in the course of our study (Table II). In function I, a combination mainly of maximum temperature $\left(\mathrm{T}_{\mathrm{MAX}}\right)$, relative humidity $\left(\mathrm{RH}_{\mathrm{AVG}}\right)$, precipitation (RAIN) and number of available pollen plants (P-FLO) accounted for up to $77 \%$ of the variations in timing of pollen collection $\left(r_{\mathrm{S}}^{2}, \mathrm{~F}_{\mathrm{ON}}=34.5 \%\right.$; $\mathrm{F}_{\text {PEAK }}=76.9 \% ; \mathrm{F}_{\text {END }}=73.7 \%$ ), number of collected plant species $\left(r_{\mathrm{S}}{ }^{2}, \mathrm{P}-\mathrm{COL}=67.7 \%\right)$ and broodcell construction $\left(r_{\mathrm{S}}{ }^{2}, \mathrm{CONST}=48.8 \%\right)$. Here, an increase in $\mathrm{T}_{\text {MAX }}$ and, respectively, a decrease in $\mathrm{RH}_{\mathrm{AVG}}$, RAIN and P-FLO accounted for a decrease in colony activity (see different signs of structure coefficients in Table II). In function II, variation was attributed mainly to the time of sunrise (SUN), which accounted for more than $50 \%$ of the variation in foraging onset $\left(r_{\mathrm{S}}^{2}\right.$, $\mathrm{F}_{\mathrm{ON}}=54.6 \%$ ). Here, an earlier sunrise was related to an earlier foraging onset (same signs of $r_{\mathrm{S}^{-}}$ SUN and $r_{\mathrm{S}}-\mathrm{F}_{\mathrm{ON}}$; Table II). In function III, variation was attributed mainly to the number of available pollen sources (P-FLO), which accounted for more than $50 \%$ of the variation in the maximum number of foragers $\left(r_{\mathrm{s}}{ }^{2}\right.$, $\mathrm{F}_{\text {MAX }}=53.9 \%$; Table II). Here, an increasing flower offer was related to an increasing foraging force (same signs of $r_{\mathrm{S}}-\mathrm{P}-\mathrm{FLO}$ and $r_{\mathrm{S}}-\mathrm{F}_{\mathrm{MAX}}$; Table II).

\subsection{Floral origin of pollen collected by foragers}

In the course of our study, we identified a total of 14 pollen types collected by M. subnitida (Electronic Supplemental Material). The average number of pollen types collected per colony (P$\mathrm{COL}$ ) varied during our study period between 
$4.5 \pm 0.6$ and $1.0 \pm 0.0$ pollen types (Figure 2c; Table I). In the more humid months (May 2011 through August 2011, and February 2012 to May 2012), bees collected pollen mostly at massflowering trees (Mimosa arenosa/Mimosa caesalpiniifolia, Mimosa tenuiflora, Pityrocarpa moniliformis ) and shrubs with poricidal flowers (Chamaecrista calycioides, Chamaecrista duckeana, Senna obtusifolia, Senna uniflora, Senna trapchpus). Pollen of these plants accounted for $50 \%$ (February 2012), $75 \%$ (May 2011, June 2011), or $100 \%$ (July 2011, August 2011, March 2012, April 2012, May 2012) of the collected pollen types (Electronic Supplemental Material). In the hottest and driest months (September 2011 to January 2012), pollen foraging was extremely reduced. Consequently, we were not successful in capturing foragers for pollen analysis (Figure 2c; Table I). The only month in the hot/dry season with elevated pollen foraging activity of all four studied colonies was November 2011 (Figure 2a, b; Table I). This temporary increase in collecting activity was due to the blooming of a mass-flowering tree species (Anadenanthera colubrina) in the study area (Electronic Supplemental Material).

\section{DISCUSSION}

Climatically unpredictable environments pose a challenge to highly eusocial bees. The seasonally uncertain availability of food and, sometimes, year-long lasting dry periods owing to unreliable precipitation (Prado 2003) render the maintenance of perennial colonies extremely difficult. In the present study, we evaluated the survival strategy of M. subnitida (Apidae, Meliponini) in the tropical Brazilian dry forest, the Caatinga. M. subnitida is one of the few eusocial bee species that naturally occur in this biome (Zanella 2000; Zanella and Martins 2003) characterised through elevated annual temperatures and extended periods of drought (Prado 2003). Here, dry-hot seasons and short, intermittent rainy-hot seasons do not occur at predictable times of the year (Figure 1). Consequently, there are no reliable abiotic cues that may indicate forthcoming seasonal changes. Bees living in this or similarly unpredictable ecoregions, therefore, have to react
Figure 2. Variation of colony activity of Melipona subnitida in the course of our study. a Monthly average pollen foraging times of the four investigated colonies (differently shaded bars). Bars indicate the period between foraging onset (lower end of bar) and foraging end (upper end of bar). The line within the bars indicates the time of peak activity. b Monthly average of the maximum number of pollen foragers returning to the four studied colonies in a 5-min interval ( $\left.\mathrm{F}_{\mathrm{MAX}}\right)$. c Monthly variation in the number of pollen types collected by each of the four studied colonies (differently shaded bars) and total number of different pollen types when combining the colony data (open circles). d Variation in brood cells construction. Given are monthly averages of brood cells built per day by each of the four studied colonies (differently shaded bars, see legend).

immediately to any given change in the environment, either by adjusting their behaviour to the respective ambient condition or by abandoning the area when conditions are unfavourable (Schneider and McNally 1992a,b; Winston 1992; Freitas et al. 2007).

Few data exist so far on the survival strategies of highly eusocial bees in the Brazilian tropical dry forest. Despite the native occurrence of approximately 20 known species of stingless bees (Zanella 2000), the currently most abundant highly eusocial bee in most areas of the Caatinga is the Africanised honey bee (Aguiar and Zanella 2005), a South American hybrid of the African honey bee Apis mellifera scutellata and European races. Contrary to pure European races, the Africanised honey bee, which had been introduced into the Brazilian Northeast in the 1960s, has succeeded in establishing wild populations in this region (Freitas et al. 2007). Even so, only a small percentage of the colonies persist in the hottest and driest parts of the Caatinga all year round. The vast majority of the colonies abandon the area in periods of food and water scarcity and migrate to regions of greater resource abundance (Freitas et al. 2007). This resource-induced absconding is a well-known characteristic of $A$. mellifera scutellata both in Africa (Schneider and Blyther 1988; McNally and Schneider 1992; Schneider and McNally 1992a,b) and in South America (Rinderer 1988; Winston 1992; Freitas et al. 2007). Here, a colony's decision to abscond or persist in the area is influenced by a combination of ambient factors and colony condition 

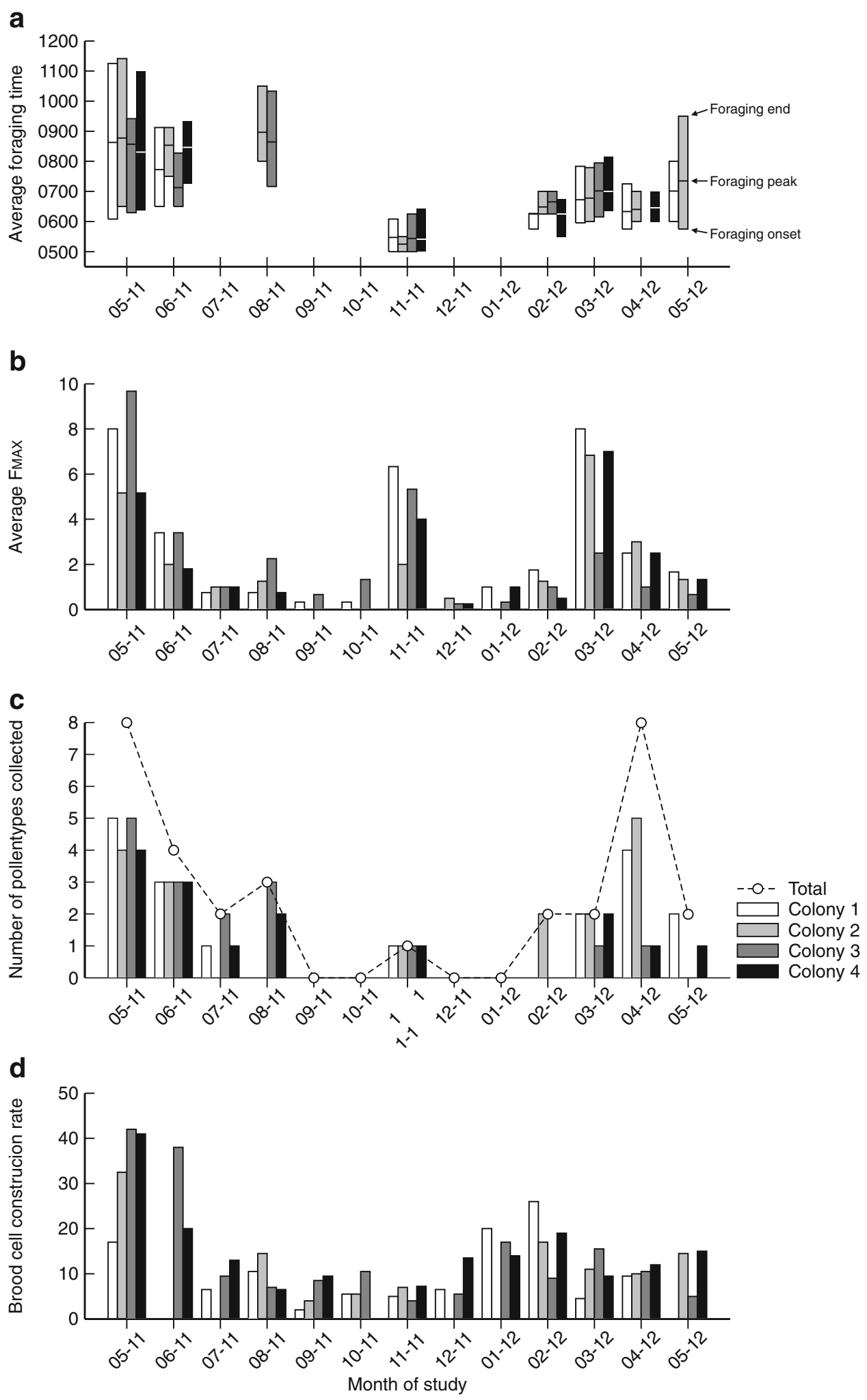


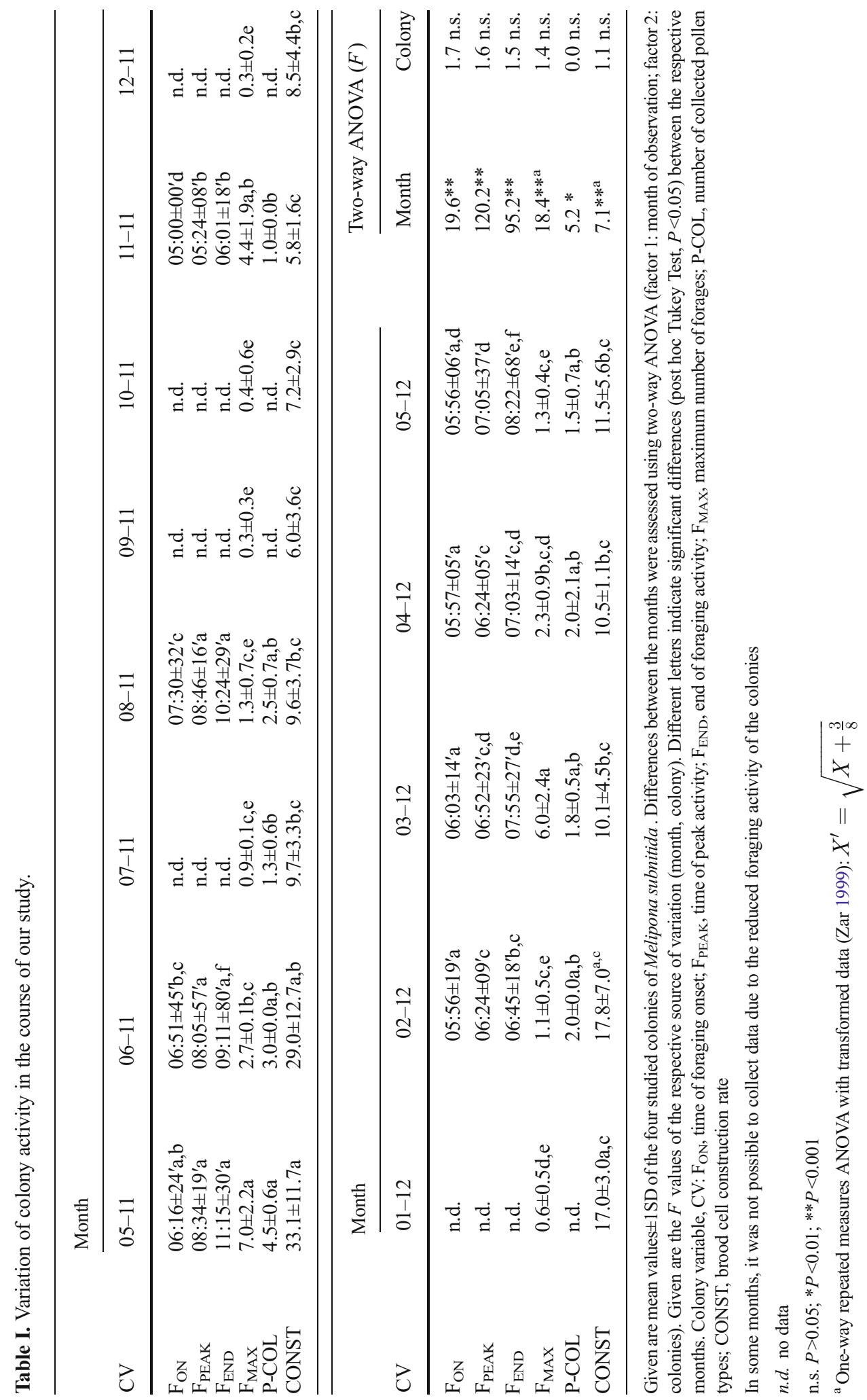




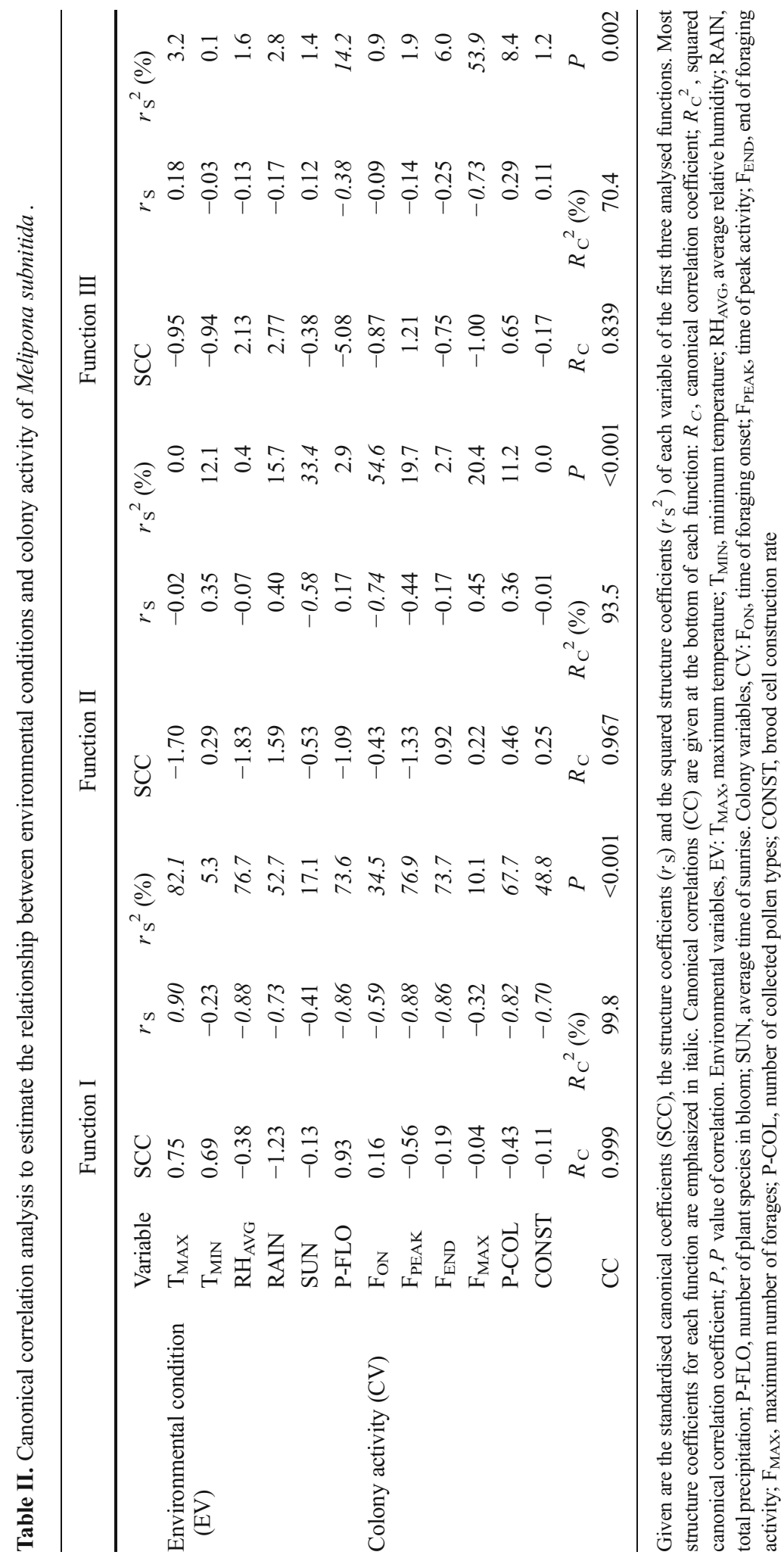


(Schneider and McNally 1992b). The main environmental trigger for absconding is the lack of flowering resources (Rinderer 1988; Schneider and McNally 1992b; Winston 1992). In the Caatinga, additional abiotic factors may be the elevated temperatures and the concomitant lack of water during dry periods (disturbance-induced absconding) (Winston 1992; Freitas et al. 2007). Elevated temperatures increase the necessity of brood thermoregulation, accomplished by honey bees either through ventilation (elevated use of energy reserves) or evaporation (water collection necessary) (Lindauer 1954; Nicolson 2009). However, the lack of water in the environment and the reduced energy supply render the vital, active down-regulation of the nest temperature difficult. Thus, colonies with little energy reserves will search for cooler or wetter areas or regions with higher resource availability rather than utilising the stored honey to survive (Schneider and McNally 1992b; Winston 1992; Freitas et al. 2007).

In contrast to honey bees, stingless bees rarely abandon their nest, owing mainly to the fact that mated meliponine queens are unable to fly. Thus, colonies would have to leave their queen behind when migrating, which would result in an initial reproductive deficit when establishing the new nest (Michener 1974). This disadvantage of absconding suggests the existence of alternative adaptive strategies in stingless bees to cope with unpredictable periods of diminished resource abundance. Our study shows that $M$. subnitida tightly adjusted its colony activity to the respective environmental conditions (Figure 3), which suggests the following adaptive strategy: Colonies invest in foraging and brood production only when food sources are abundant in the environment. In periods of reduced forage availability, colonies reduce adult activity and brood production to virtually zero, thereby economising the amassed food reserves, which are important to re-initiate colony activity (foraging, brood production) once resources become available again.

Ambient factors that directly affected pollen collection were maximum temperature, the time of sunrise and the availability of potential pollen sources (Table II). The influence of the abiotic factors (temperature and sunrise) on foraging activity is putatively related to physiological characteristics of the bees (Hrncir and Maia-Silva 2013), such as vision (minimum light condition necessary to initiate flight — earlier sunrise associated with earlier foraging activity; Table II) or lethal temperature (maximum acceptable flight temperature-higher maximum temperatures associated with earlier foraging; Table II; see also Electronic Supplement Material for temperature range in which pollen foraging occurred). The humidity related parameters (relative humidity and precipitation) probably affected pollen foraging indirectly through their influence on resource abundance (Figure 3). Thus, during the wetter months of our study, when many flowering plants were available, the colonies strongly increased their foraging effort (maximum number of foragers and collecting time) and reduced it during the dry months.

Changes in pollen foraging in the course of our study were accompanied by changes in brood-cell construction (Figure 2; Table II). Although a direct regulatory influence of ambient factors on both colony external and internal activities is possible, we postulate that only pollen foraging was directly affected by the environment. The observed concomitant variations in brood production were putatively caused by variations in pollen reserves within the nest (Roubik 1982; Schneider and McNally 1992a, 1994; Figure 3). Pollen foraging activity directly influences the amount of pollen available within the nests of highly eusocial bees, which is primarily used for brood rearing (Roubik 1982; Schneider and McNally 1992a, 1994). Thus, in line with similar findings for other stingless bee species (Roubik 1982; Ribeiro et al. 2003; Nunes-Silva et al. 2010a) and for honey bees (Seeley 1985; Schneider and McNally 1992b), M. subnitida down-regulated its brood production in periods of food scarcity and concomitant decline in pollen collection (Figure 3). Owing to the reduced rearing of new brood, the populations of bee colonies decrease over time (Free and Racey 1968). This, together with the reduced activity of the remaining adults, results in a diminished consumption of the stored food reserves, which are fundamental for the colonies to quickly restart their activity (foraging and brood production) as soon as forage availability begins 


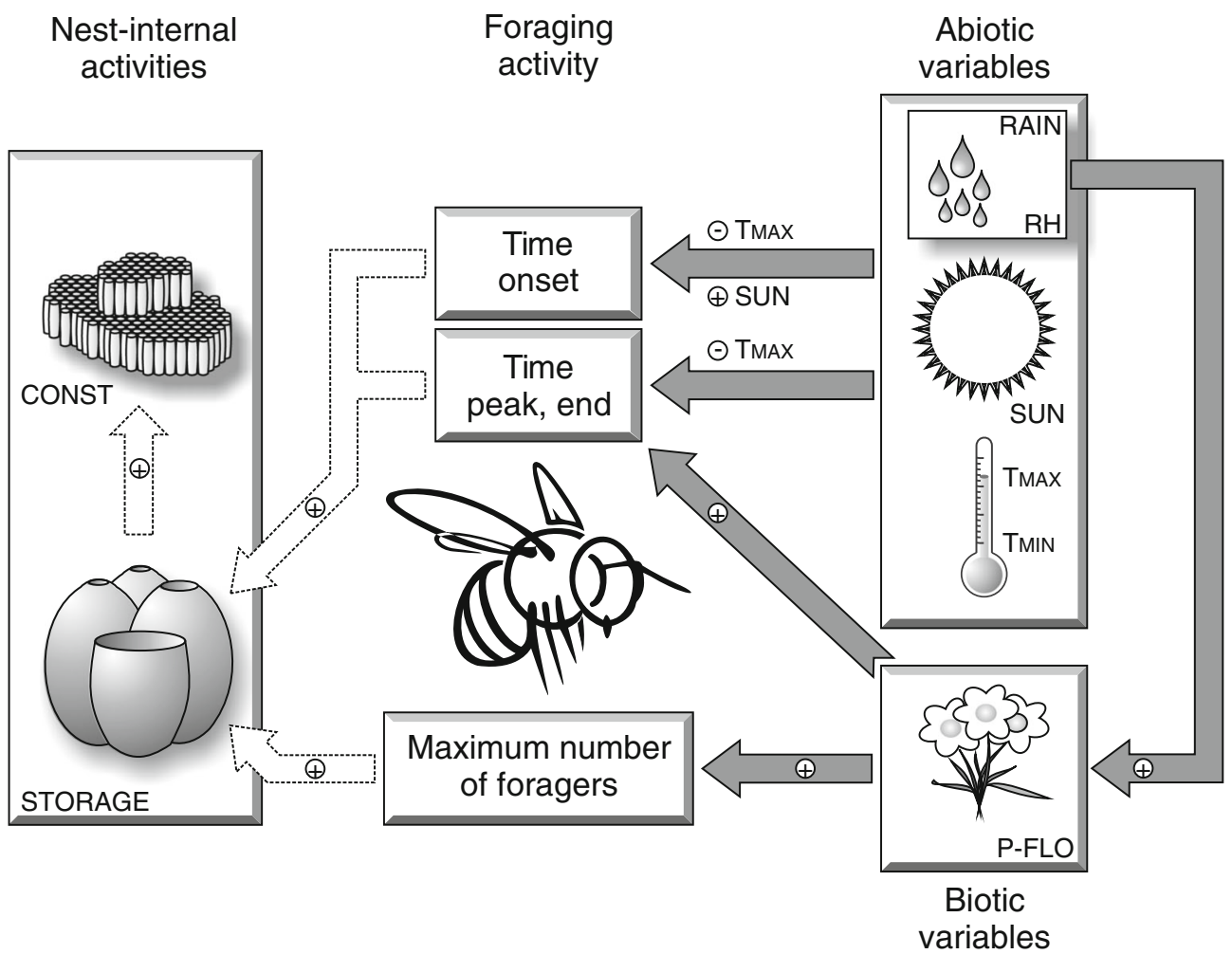

Figure 3. Influence of environmental factors on the colony activity of Melipona subnitida in the Brazilian dry forest. The monthly variations of abiotic and biotic environmental variables resulted in variations of the bees' foraging activity and brood-cell construction rate. Grey-filled arrows indicate the associations indicated by canonical correlation analysis in the present study (plus symbol positive correlation, minus symbol negative correlation; for details see Table II). Dashed arrows indicate the suggested relationship between foraging activity and brood production through the putative effect of pollen collection on pollen reserves. RAIN precipitation, $R H$ average relative humidity, $S U N$ average time of sunrise, $T_{M A X}$ maximum temperature, $T_{M I N}$ minimum temperature, CONST brood-cell construction rate, STORAGE food reserves in the nest.

to increase (McNally and Schneider 1992; Ribeiro et al. 2003; Nunes-Silva et al. 2010a).

In addition to the resource-related adjustment in foraging activity and concomitant adjustment in brood production, M. subnitida selectively foraged at the most lucrative resources. In the course of our study, the foragers collected pollen at only few of the available sources (14 pollen types collected, 63 potential pollen source species in bloom), predominantly at mass-flowering trees (Electronic Supplemental Material), or shrubs with poricidal anthers. Mass-flowering plants, on the one hand, produce an excessive number of flowers each day, thus providing large amounts of pollen and/or nectar to flower visitors (Gentry
1974; Bawa 1983). This, eventually, offers an excellent opportunity for social bees to amass food reserves within their nests (Wilms and Wiechers 1997; Ramalho 2004). Shrubs with poricidal flowers, on the other hand, do not produce many flowers. Each flower, however, contains large amounts of pollen, which is released only when the flowers are vibrated by visitors (buzz pollination) (Buchmann 1983). Consequently, poricidal flowers are highly attractive for Melipona species and other bees capable of buzz pollination (Nunes-Silva et al. 2010b).

Both the observed tight association between colony activity and resource availability, and the allocation of foragers towards lucrative pollen 
sources provide an insight into how M. subnitida is able to maintain perennial colonies despite the environmental unpredictability of the Brazilian tropical dry forest: Colonies minimise any unnecessary costs related to foraging and brood rearing when forage availability is low, and maximise their food intake as soon as resources are available in the environment by selectively foraging on the most profitable food sources. Consequently, the colonies amass high amounts of food during short periods of elevated resource abundance and use their reserves economically during the extended periods of drought.

\section{ACKNOWLEDGMENTS}

We would like to thank CETAPIS (Mossoró/RN) for providing experimental facilities, Rubens Teixeira de Queiroz for botanical identification and the students of the Laboratory of Behavioral Ecology for their help with the data collection. Our sincere thanks also go to two anonymous reviewers whose critical comments helped to improve the manuscript.This study complies with current Brazilian laws and was financially supported by CAPES (CMS) and CNPq (VLIF: 482218/20100; MH: 304722/2010-3, 481256/2010-5).

\section{Stratégies de survie des abeilles sans aiguillon (Melipona subnitida) dans un environnement incertain: la forêt sèche tropicale brésilienne}

Caatinga / ressources florales / approvisionnement en pollen / construction des cellules du couvain

Überlebensstrategien von Stachellosen Bienen (Melipona subnitida) unter nichtvorhersehbaren Umwelbedingungen in einem tropischen Trockenwald in Brasilien

Caatinga / Blütenquellen / Pollensammeln / Brutzellbau

\section{REFERENCES}

Aguiar, C.M.L., Zanella, F.C.V. (2005) Estrutura da comunidade de abelhas (Hymenoptera: Apoidea: Apiformis) de uma área na margem do domínio da Caatinga (Itatim, BA). Neotrop. Entomol. 34, 15-24

Bawa, K.S. (1983) Patterns of flowering in tropical plants. In: Jones, C.E., Little, R.J. (eds.) Handbook of
Experimental Pollination Biology, pp. 394-410. Van Nostrand Reinhold, New York

Buchmann, S.L. (1983) Buzz pollination in angiosperms. In: Jones, C.E., Little, R.J. (eds.) Handbook of Experimental Pollination Biology, pp. 73-113. Van Nostrand Reinhold, New York

Cámara, J.Q., Sousa, A.H., Vasconcelos, W.E., Freitas, R.S., Maia, P.H.S., Almeida, J.C., Maracajá, P.B. (2004) Estudos de meliponíneos, com ênfase a Melípona subnitida D. no município de Jandaíra, RN. Rev. Biol. Ciênc. Terra 4, 1-6

Camargo, J.M.F., Pedro, S.R.M. (2012) Meliponini Lepeletier, 1836. In: Moure, J.S., Urban, D., Melo, G.A.R. (eds.) Catalogue of Bees (Hymenoptera, Apoidea) in the Neotropical Region. Available at http://www.moure.cria.org.br/ catalogue

Eltz, T., van der Brühl, C.A., Kaars, S., Chey, V.K., Linsenmair, K.E. (2001) Pollen foraging and resource partitioning of stingless bees in relation to flowering dynamics in a Southeast Asian tropical rainforest. Insect. Soc. 48, 273-279

Erdtman, G. (1960) The acetolized method-a revised description. Sven. Bot. Tidskr. 54, 561-564

Free, J.B., Racey, P.A. (1968) The effect of the size of honeybee colonies on food consumption, brood rearing and the longevity of the bees during winter. Entomol. Exp. Appl. 11, 241-249

Freitas, B.M., Sousa, R.M., Bomfim, I.G.A. (2007) Absconding and migratory behaviors of feral Africanized honey bee (Apis mellifera L.) colonies in NE Brazil. Acta Sci. Biol. Sci. 29, 381-385

Gentry, A. (1974) Flowering phenology and diversity in tropical Bignoniaceae. Biotropica 6, 64-68

Hotelling, H. (1936) Relations between two sets of variables. Biometrika 28, 321-377

Hrncir, M., Maia-Silva, C. (2013) On the diversity of foraging-related traits in stingless bees. In: Vit, P., Pedro, S.R.M., Roubik, D. (eds.) Pot-Honey: A Legacy of Stingless Bees, pp. 201-215. Springer, New York

Kajobe, R., Echazarreta, C. (2005) Temporal resource partitioning and climatological influences on colony flight and foraging of stingless bees (Apidae; Meliponini) in Ugandan tropical forests. Afr. J. Ecol. 43, 267-275

Kleinert-Giovannini, A. (1982) The influence of climatic factors on flight activity of Plebeia emerina Friese (Hymenoptera, Apidae, Meliponinae) in winter. Rev. Bras. Entomol. 26, 1-13

Lindauer, M. (1948) Über die Einwirkung von Duft- und Geschmacksstoffen sowie anderer Faktoren auf die Tänze der Bienen. Z. Vergl. Physiol. 31 , 348-412

Lindauer, M. (1954) Temperaturregulierung und Wasserhaushat im Bienenstaat. Z. Vergl. Physiol. 36, 391-432

Machado, I.C., Lopes, A.V. (2004) Floral traits and pollination systems in the Caatinga, a Brazilian tropical dry forest. Ann. Bot. 94, 365-376 
Maia-Silva, C., da Silva, C.I., Hrncir, M., de Queiroz, R.T., Imperatriz-Fonseca, V.L. (2012) Guia de Plantas Visitadas por Abelhas na Caatinga. Editora Fundação Brasil Cidadão, Fortaleza

Martins, C.F., Cortopassi-Laurino, M., Koedam, D., Imperatriz-Fonseca, V.L. (2004) Espécies arbóreas utilizadas para nidificação por abelhas sem ferrão na caatinga (Seridó, PB; João Câmara, RN). Biota Neotrop. 4, 1-8

McNally, L.C., Schneider, S.S. (1992) Seasonal patterns of growth, development and movement in colonies of the African honey bee, Apis mellifera scutellata, in Africa. Insect. Soc. 39, 167-179

Michener, C.D. (1974) The Social Behavior of the Bees: A Comparative Study. Harvard University Press, Cambridge

Michener, C.D. (2007) The Bees of the World. The John Hopkins University Press, Baltimore

Michener, C.D. (2013) The Meliponini. In: Vit, P., Pedro, S.R.M., Roubik, D. (eds.) Pot-Honey: A Legacy of Stingless Bees, pp. 3-17. Springer, New York

Nagamitsu, T., Momose, K., Inoue, T., Roubik, D.W. (1999) Preference in flower visits and partitioning in pollen diets of stingless bees in an Asian tropical rain forest. Res. Popul. Ecol. 41 , 195-202

Nicolson, S.W. (2009) Water homeostasis in bees, with the emphasis on sociality. J. Exp. Biol. 212, 429-434

Nunes-Silva, P., Hilário, S. D., Santos Filho, P. S., Imperatriz-Fonseca, V. L. (2010a) Foraging activity in Plebeia remota, a stingless bees species, is influenced by the reproductive state of a colony. Psyche. Article ID 241204, 1-16

Nunes-Silva, P., Hrncir, M., Imperatriz-Fonseca, V.L. (2010b) A polinização por vibração. Oecol. Australis 14, 140-151

Prado, D. (2003) As Caatingas da América do Sul. In: Leal, I.R., Tabarelli, M., Silva, J.M.C. (eds.) Ecologia e Conservação da Caatinga, pp. 75-134. Editora Universitária UFPE, Recife

Ramalho, M. (2004) Stingless bees and mass flowering trees in the canopy of Atlantic Forest: a tight relationship. Acta Bot. Bras. 18, 37-47

Ribeiro, M.F., Imperatriz-Fonseca, V.L., Santos Filho, P.S. (2003) A interrupção da construção de células de cria e postura em Plebeia remota (Holmberg) (Hymenoptera, Apidae, Meliponini). In: Melo, G.A.R., Alvesdos-Santos, I. (eds.) Apoidea Neotropica: Homenagem aos 90 Anos de Jesus Santiago Moure, pp. 177-188. Editora UNESC, Criciúma

Rinderer, T.E. (1988) Evolutionary aspects of the Africanization of honey-bee populations in the Americas. In:
Needham, G.R., Page Jr., R.E., Delfinado-Baker, M., Bowman, C.F. (eds.) Africanized Honey Bee and Bee Mites, pp. 13-28. Ellis Horwood Ltd., Chichester

Roubik, D.W. (1982) Seasonality in colony food storage, brood production and adult survivorship: studies of Melipona in tropical forest (Hymenoptera: Apidae). J. Kansas Entomol. Soc. 55, 789-800

Schneider, S., Blyther, R. (1988) The habitat and nesting biology of the African honey bee Apis mellifera scutellata in the Okavango River Delta, Botswana. Afr. Insect. Soc. 35, 167-181

Schneider, S.S., McNally, L.C. (1992a) Seasonal patterns of foraging activity in colonies of the African honey bee, Apis mellifera scutellata, in Africa. Insect. Soc. 39, 181-193

Schneider, S.S., McNally, L.C. (1992b) Factors influencing seasonal absconding in colonies of the African honey bee, Apis mellifera scutellata. Insect. Soc. 39, 403423

Schneider, S.S., McNally, L.C. (1994) Developmental patterns associated with founding and swarming in colonies of the African honey bee race, Apis mellifera scutellata Lepeletier. Apidologie 25, 530-539

Seeley, T.D. (1985) Honeybee Ecology: A Study of Adaptation in Social Life. Princeton University Press, Princeton

Velloso, A.L., Sampaio, E.V.S.B., Pareyn, F.G.C. (2002) Ecorregiões Proposta Para o Bioma Caatinga, 1st edn. Associação Plantas do Nordeste, Instituto de Conservação Ambiental - The Nature Conservancy do Brasil, Recife

Wilms, W., Wiechers, B. (1997) Floral resource partitioning between native Melipona bees and the introduced Africanized honey bee in the Brazilian Atlantic Rain Forest. Apidologie 28, 339-355

Wilson, E.O. (1971) The Insect Societies. The Belknap Press of Harvard University Press, Cambridge

Winston, M.L. (1992) The biology and management of Africanized honey bees. Annu. Rev. Entomol. 37, 173-193

Zanella, F. (2000) The bees of the Caatinga (Hymenoptera, Apoidea, Apiformes): a species list and comparative notes regarding their distribution. Apidologie 31, 579592

Zanella, F.C.V., Martins, C.F. (2003) Abelhas da Caatinga: biogeografia, ecologia e conservação. In: Leal, I.R., Tabarelli, M., Silva, J.M.C. (eds.) Ecologia e conservação da Caatinga, pp. 75-134. Editora Universitária UFPE, Recife

Zar, J.H. (1999) Biostatistical Analysis. Prentice Hall Inc., Upper Saddle River 